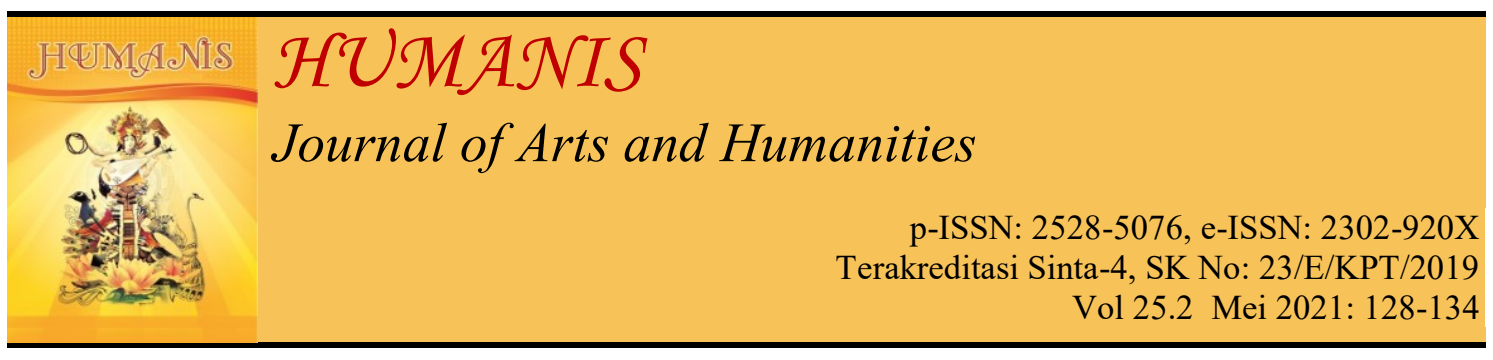

\title{
Swearing and Taboo Words by The Main Character in I, Tonya Movie
}

\author{
Komang Yuly Sintia Dewi, Ketut Santi Indriani
}

Udayana University, Denpasar, Bali, Indonesia

Correspondence email: yulysintia40799@gmail.com, kt.santi.indriani@unud.ac.id

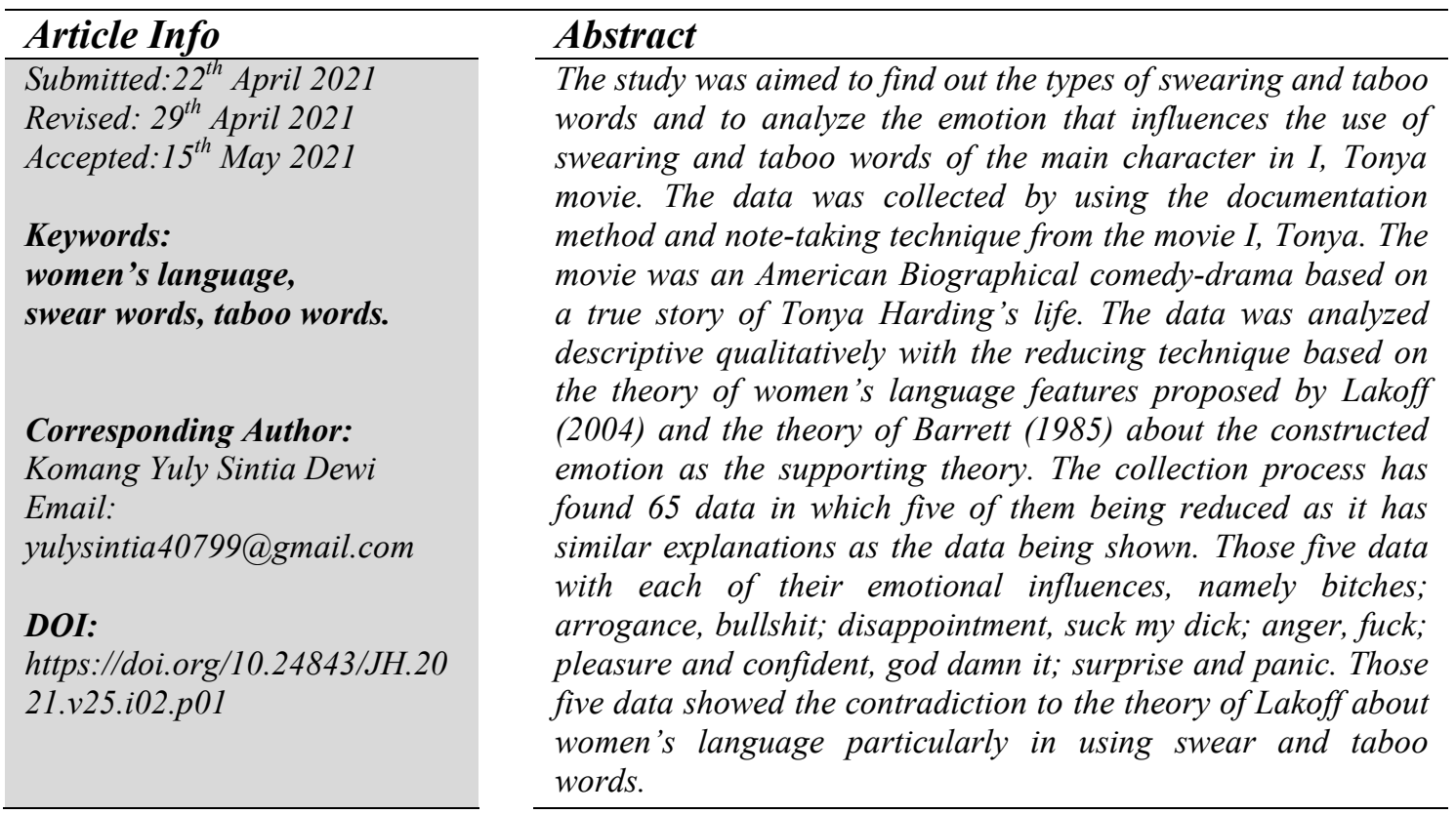

\section{INTRODUCTION}

Language is a communication tool to express the ideas and emotion of its speaker (Sapir, 1921:8). The use of language is the reality of communication interaction in society (Nengsih, 2014:83).

According to Wardhaugh (2010:316), the use of language in society was determined by the gender in which its influence the form of the language, the purpose of speech and the way of speaking. In general, the use of language is categorized into men's and women's language. Lakoff (2004) in her book, "Language and Woman's Place: Text and Commentaries", proposed linguistic features that differentiate the way of how men and women speak. She discovered the linguistic feature in women's language namely lexical hedge, tag question, rising intonation, empty adjective, precise color term, intensifier, superpolite form, hypercorrect grammar, swearing and taboo word and emphatic stress. According to her, men's language is more assertive, mature, and openly spoken. Meanwhile, women's language is immature, indecisive, using figurative words, careful when expressing things and often use refined and polite words.

However, these days, several features of the theory proposed by Lakoff (2004) sometimes is in contrast to the language use by men and women. The contrast is particularly seen in the use of swearing and taboo words. Partridge 
(1984:144) stated that the purpose of the swearwords is to insult, curse and mock somebody with obscene words so that people these days often use a lot of swearing in their daily life. This implies that both men and women nowadays have the same usage of swearing and taboo words to express their feeling, by which women do not always avoid the use of swear words. This clearly contradicts Lakoff's theory that states women's language is gentle and polite, whereas, in the real-life, there are some women from certain social circumstances who often use swear words in their utterances (Trudgill, 2000:25).

Therefore, the study about swearing and taboo words in I, Tonya movie is an interesting topic to be discussed since it shows a lot of words that are considered as swear and taboo words used by the main character, Tonya Harding. Besides, this movie is based on a true story that shows the contrary of Lakoff's theory with the reality of how women use their language particularly in the feature of swearing and taboo words.

Based on the foregoing introduction, this study aims to find out the types of swearing and taboo words and to analyze the emotion that influences the use of swearing and taboo words of the main character in I, Tonya movie.

\section{Literature Review}

There were several previous studies related to the swearing and taboo words.

Nangune (2014) discovered that the swearing and taboo words in reality are used by many people and have several situations such as to insult someone, to emphasize a question and statement. Similarly, Anggita (2015) found the change of attitude towards the function of swearing and taboo words. According to her, the changes happened because the legal sanctions are not sufficiently strict to accept taboo words. On the other hand, Wardani (2016) conclude that the use of the word damn is more commonly found in negative prosodies. She found that the assumption of men uses swear words more than women is not proven. The analysis showed that the same number of men and women use the word damn.

Hidayati (2016) discussed about the uses of swear words by the antagonist in this film the Barbie and 12 Dancing Princesses. Khairunnisa (2017), found that the words curse and swear do not always mean rude but also express feelings of pleasure and admiration for an object or situation. Sanjaya (2018) found the use of taboo words in daily speech among the people based on their cultural, psychology and social condition. The different situation of sociology and psychology of the speaker may also produce the different category of taboo words. Noviantari (2019), discovered the stereotype towards women as subordinate person forces them to be limited in acts however, the women's position today is going to be equal to men's, like having the same opportunity as men in many fields such as education, politic, economic, etc. Lastly, Badari and Setyowati (2019) analysed Michelle Obama's language feature as the most influential and respected political figures of First Lady in USA. They found that Michelle Obama was not reluctant to use male language characteristics in her formal activities and proved that women can also use men's language characteristics rather than just using their own language characteristics.

From all of those studies, it can be concluded that the use of Lakoff's theory does not seem to make any difference between men's and women's language since there are many factors that support the use of swearing and taboo words by women nowadays.

\section{METHOD AND THEORY}

This study is focused on identifying the types and emotions of swearing and 
taboo words which were used by the main character in I, Tonya. The main data of this study was taken from the English subtitle of I, Tonya movie. I, Tonya was a 2017 American Biographical comedy-drama film directed by Craig Gillespie and produced by Tom Ackerley, Margot Robbie, Steven Rogers and Bryan Unkeless. The movie was written by Steven Rogers based on the true story of Tonya Harding, a former figure skater who was allegedly involved in the assault of his colleague, Nancy Kerrigan, in 1994. The movie can be considered to be unique, as it based on a true story and contained plenty of swearing and taboo words that were uttered by the main character as a woman.

In this study, the data was collected by the documentation method through some steps. The collection process has found 65 data. The first step was watching and listening intensively to the utterance of the main character in $I$, Tonya movie on Netflix. The second step was identifying the clauses, phrases or words that are considered as swearing and taboo words. The third step was noting the utterance and the minute when the swearing and taboo words was said and ordering it into a list.

The data was analyzed in the descriptive qualitative method that through some steps. The first step was analyzing the utterance of Tonya Harding which contained the swear and taboo words based on the theory of Lakoff (2004). The second step was describing the use of swear and taboo words based on Tonya's utterances. The third step was explaining the emotional feeling that influence the feature of swearing and taboo words in the Tonya's utterance based on the theory of constructed emotion by Barrett (1985). In order to streamline the analysis process, the researcher used five from 65 data to be discussed because these five data have represented the other data of the swear and taboo words in Tonya's utterance.

The method used to present the analysis was the informal method that is completed in several steps. First, the data were listed and numbered then the data were presented in the form of paragraphs. Second, the data were accompanied by the minute when the words or sentences were uttered by Tonya. Lastly, the data is explained in term of the use of swearing and taboo words and described the utterances according to the theory of constructed emotion by Barret (1985)

\section{Theory of Women's Language}

This study uses the theory of women's language features proposed by Lakoff (2004). She defined the types of women's language features into ten types; lexical hedge, tag question, rising intonation, empty adjective, precise color term, intensifier, superpolite form, hypercorrect grammar, swearing and taboo word and emphatic stress. Since this study's focus only on swearing and taboo words: thereby the explanation can be seen as follows.

\section{Swearing and Taboo Words}

According to Lakoff (2004:44), men and women have different ways to express it. Women are more likely use weaker expletives to avoid the swear word such as, oh dear, goodness, oh fudge, etc. Meanwhile, men used more swear and taboo words than women. They more likely use stronger expletive, such as damn, shit, hell and so on.

Besides, according to Allan and Burridge (2006:76), the swear and taboo words are defined as something to emphasize what the speaker wants to convey and become a way to insult something or someone. In line with the previous opinion, Andersson and Hirsch (1985: 61) view swearing as an expression of feelings and emotions. This idea is also proposed by Mbaya (2002: 
224) who stated that taboo words are any kinds of words or expression in one language which are characterized by the lack of morality.

\section{Theory of Constructed Emotions}

According to Barrett (1985:114) there are six kinds of emotions in humans, namely joy, surprise, sadness, anger, fear and hatred. In its development, the swear word apart from being pronounced to express the emotion of anger, is also used as another expression, such as when amazed and surprised. Swear words also function as a form of greeting and joking for people who have a close relationship. To show expressions of anger, hate and surprise, people usually use swear words because swear words can be used to express one of these emotions.

Crystal (1987:10) said that the word swears or profanity is usually used to express the speaker's feelings, especially when they are angry. It can also be used when expressing intimacy and jokes.

\section{RESULT AND DISCUSSION}

The analysis related to the examples of swearing and taboo words used by the main characters in I, Tonya movie can be seen as follows.

\section{Data 1 \\ (00:05:53)}

Tonya : Six months later I win my first competition. I was four. Those bitches didn't know what hit 'em

The data above showed Tonya's utterance that used the swear word of bitches to indicate it. The data took place at the ice rink in Oregon when little Tonya at age four win the competition and receive the 1st place medal beaten her competitors age 7- to 9-year-old. In Tonya's utterance, she said that she won her first competition after six months joined the ice-skating club and she mocked her competitors by saying "Those bitches didn't know what hit "em". In her utterance, the swear word bitches refers to her competitors that she defeated in that competition.

According to Lakoff (2004:44), women usually used more polite language when expressing her feeling. They tend to use the positive word to soften her word. Based on the data above, Tonya's utterance is contradicted Lakoff's theory and she used the swear word bitches to emphasize her utterance and express her arrogance because she has beaten her competitors in the iceskating competition.

\section{Data 2}

(00:23:37)

Tonya : They freakin' hate me. Emily Ann fell and scored higher

Diane : Honey, you're- different.

Tonya : I'm not dressing like a retarded tooth fairy. This is bullshit.

The data above showed the conversation between Tonya and Diane, her coach when Tonya complains about her score and uttered the swear word of bullshit to indicate it. The data took place at the scoring area in The Competition of Skate America in Portland, Maine when she lost to her competitor, Emily Ann. In Tonya's conversation, it seemed that Tonya did not accept Emily's score, which had fallen while performing.

According to Lakoff (2004:44), women are more careful and avoid using harsh words. They give a smoother impression in these invective words that far from being rude. However, based on the data above, Tonya's utterance is contradicted Lakoff's theory and she used the swear word of bullshit to 
express her disappointment of Emily's score that is higher than her.

\section{Data 3}

(00:28:36)

Judge : Maybe you're just not as good as you think. Maybe you need to pick another sport.

Tonya : Suck my dick! This is fuckin' rigged!

The data above showed the conversation between Tonya and the judge when she utters the swear word of suck my dick and fuckin' to indicate it. The data took place in The Regional Competition at the ice rink in Oregon. In Tonya's conversation, it seemed that Tonya and the judges have a conflict so that Tonya uttered the words like that.

According to Lakoff (2004:44), women more likely to use weaker expletives to avoid swear words such as, oh dear, goodness, oh fudge, etc.

However, based on the data above, Tonya's utterance is contradicted Lakoff's theory and she used the swear word of suck my dick and fuckin' to express her anger because she got an unfair score and then she protested with the score she got but the judge underestimated her.

\section{Data 4}

(00:35:11)

Tonya : It was totally the most awesome thing. Cause leading up it you're like, "I can't do it! I can't. I can't." BAM! I CAN! All those people who said I couldn't make it. Well fuck you I did! I proved everyone wrong.

The data above showed Tonya's utterance that used the swear word of fuck to indicate it. The data took place in the national competition at the ice rink in Minneapolis, Minnesota when Tonya did her triple axel and being the first American woman to successfully land a triple axel in competition and she proved it to people who said she could not make it by saying "Well fuck you I did! I proved everyone wrong"

According to Lakoff (2004:44), women are very careful when expressing things and often use more refined and polite words. Based on the data above, Tonya's utterance is contradicted Lakoff's theory and she used the swear word fuck you to emphasize her utterance and express her pleasure and confidence because she did the triple axel and proved that she can do it.

\section{Data 5 \\ (00:58:51)}
Policeman : Excuse me. I'm with the Canton County Sheriff's office. I'm gonna need to talk with you.

Tonya

: God damn it, Jeff what'd you do??

The data above showed the conversation between Tonya and Jeff when the policeman approach them and then she uttered the swear word of God damn it to indicate it. The data took place at the ice rink arena in Oregon when Tonya was practicing accompanied by her coach, Diane, and her husband, Jeff. In Tonya's conversation, it seemed that Tonya confused why that policeman is looking for them.

According to Lakoff (2004:44), women have an urge to convey emotion, they barely curse using terms such as 'damn', 'shit', etc. in their speech and use 'oh goodness', 'oh dear', or the same type or swear words instead. However, based on the data above, Tonya's utterance is contradicted Lakoff's theory 
and she used the swear word of God damn it to express her surprise and panic because she knew nothing about the policeman that approached Jeff, Diane and her.

\section{CONSLUSION}

Based on the foregoing analysis in the discussion, the following points can be drawn as conclusions.

Related to the first problem, the finding showed that along with the movie, Tonya used the swear and taboo features 63 times with the type of swear word divided into 5, namely the word "fuck" 46 times, the word "shit" 15 times, the word "damn", "bitches" and "suck my dick" respectively one time. There are five from 63 examples of swearing and taboo words analyzed in I, Tonya Movie based on the theory of Lakoff (2004). Those examples are included 'bitches', 'bullshit', 'suck my dick', 'fuck' and "god damn it'. The main character used those swear words to express her feeling toward her situation in the movie. She used this feature to speak with people who have the same age or gender and close relationships such as her mother Lavona, her husband Jeff and her coach Diane. She also used the swear words to people who have different age, gender and have no close relationship with her such as the judges in the ice-skating competition.

Answering the second problem based on the theory of Barrett (1985), the emotion expressed in swearing and taboo words of Tonya's utterance is not merely to express her anger. In this data, the use of swearing and taboo word such as 'fuck' was expressing her feelings of pleasure and confidence, the word 'suck my dick' was expressing her feeling of anger, while the word 'bullshit' was expressing her disappointment, the word "bitches" was expressing her arrogance and the word 'god damn it' was expressing her surprise and panic.
From all of those five data above, it can be concluded that the use of swearing and taboo words by Tonya Harding represented the use of women's language that are in contrast to Lakoff's theory because of the influence by each construction of emotion to express the emotional feeling and situation

\section{REFERENCES}

Allan, K. and Burridge, K. (2006). Forbidden words: Taboo and the censoring of language. Cambridge: Cambridge University Press.

Andersson, L. G. and Hirsch, R. (1985). Perspectives on swearing. Gothenburg: University of Gothenburg, Department of Linguistics

Anggita, F. N. (2015). A sociolinguistic analysis of taboo words in bad teacher movie. Thesis, Yogyakarta State University, Indonesia. Retrieved from http://eprints.uny.ac.id/15998/1/Fi ka\%20Nur\%20Anggita\%20102111 44029.pdf

Badari, A. P. and Setyowati, A. (2019). An analysis of features and functions in women's speech in the talkshow united states of women summit. Journal Albion Journal of English Literature, Language, and Culture, 1(2). Retrieved from https://journal.unpak.ac.id/index.ph p/albion/article/view/1309

Barrett, L. F. (1985). How emotions are made: The secret life of the brain. Houghton Mifflin Harcourt.

Crystal, D. (1987). The Cambridge Encyclopedia of Language. Cambridge: Cambridge University Press 
Hidayati, N. N. (2016). Language and gender: Study of the linguistic characteristics of men and women in children's films. Al Hikmah: Journal of Islamic Studies, 6 (1). Retrieved from http://ejournal.kopertais4.or.id /pantura/index.php/alhikmah/article /view/2796

Khairunnisa, U. H. (2017). The curse word in the novel Out by Natsuo Kirino: Sociolinguistic review. Doctoral dissertation, Andalas University. Retrieved from http://scholar.unand.ac.id/28113/

Lakoff, R. (2004). Language and woman's place: Text and commentaries (Vol. 3). Oxford University Press, USA.

Mbaya, N. (2002). Linguistic taboo in African marriage context: A study of oromo laguu. Nordic Journal of African Studies.11, 224-23.

Nangune, L. M. (2014). Analysis of the use of profane vocabulary in American pie 7 "book of love" film. Journal of Electronic. Faculty of literature, Ratulangu University, 3 (2). Retrieved from https://media.neliti.com/media/publ ications/82571-ID-kata-kata makian-dalam-film-a-good-dayt.pdf

Nengsih, S. W. (2014). Directive speech acts in Banjar family domain, 83126. Banjarbaru: South Kalimantan.

Neon. R. (2017). I, Tonya movie. Retrieved on April 7, 2021 from https://www.itonyamovie.com/
Noviantari, D. T. (2019). Women's language variety in HeForShe conversation with Emma Watson on International women's day. Faculty of Cultural Studies, University of North Sumatera. Retrieved from http://repositori.usu.ac.id/handle/12 $3456789 / 16023$

Partrige, E. (1984). A dictionary of slang and unconventional English. Cambridge: Cambridge University Press

Sanjaya. (2018). An analysis of English taboo words in movie Get Hard, Faculty of Cultural studies, University of North Sumatera. Retrieved from http://repositori.usu.ac.id/bitstream/ handle/123456789/5483/12070502 4.pdf? sequence $=1 \&$ is Allowed $=y$

Sapir, E. (1921). Language: An introduction to the study of speech. New York: Harcourt, Brace.

Trudgill, P. (2000). Sociolinguistics: An introduction to language and society. London: Oxford University Press.

Wardani, E. (2016). The word damn: The analysis on its semantic prosody and social aspects in British National Corpus (Bnc). Doctoral dissertation, Universitas Brawijaya. Retrieved from http://repository.ub.ac.id/102034/

Wardhaugh, R., (2010). An introduction to sociolinguistics (Vol. 28). John Wiley \& Sons. 